tenderness, and nodules on the uterosacral ligaments. The diagnosis should be verified laparoscopically before treatment is begun. Considerable degeneration of the endometriosis occurs after two months of medical treament, and symptoms should therefore diminish. Uncontrolled evidence suggests that laparoscopic ablation of endometriotic implants improves symptoms. ${ }^{14}$ Successful surgical and medical treatments are both followed by an appreciable rate of recurrence.

Because the denominator for the visual diagnosis of endometriosis has changed recently, the true incidence and prevalence of the disease are unknown. Pain is the main indication for treatment, and the disease should be regarded as chronic and relapsing rather than as acute phenomenon treatable by a single medical or surgical intervention.

ERIC J THOMAS

Professor of Obstetrics and Gynaecology,

University of Southampton, Princess Anne Hospital,

Southampton SO9 4HA
Audebert A, Backstrom T, Barlow DH, Benagiano G, Brosens I, Buhler K, et al. Endometriosis 1991: a discussion document. Hum Reprod 1992;7:432-5.

Vercellini P, Bocciolone L, Crosignani PG. Is mild endometriosis always a disease? Hum Reprod 1992;7:627-9.

3 Redwine DB. Age-related evolution in color appearance of endometriosis. Fertil Steril 1987;48. 1062-3.

4 Donnez J, Nisolle M, Casanas-Roux F. Three dimensional architectures of peritoneal endometriosis. Feril Steril 1992;57:980-3.

5 Thomas EJ, Prentice A. The aetiology and pathogenesis of endometriosis. Reproductive Medicine Review 1992;1:21-36.

6 Vessey MP, Villard-Mackintosh L, Painter R. Epidemiology of endometriosis in women attending family planning clinics. $B M \mathcal{F} 1$ 1993;306:182-4.

7 Mahmood TA, Templeton A. Prevalence and genesis of endometriosis. Hum Reprod 1991;6:544-9.

8 Thomas EJ, Cooke ID. The impact of gestrinone upon the course of asymptomatic endometriosis. $B M 7$ 1987;294:272-4.

9 Mahmood TA, Templeton A. The impact of treatment on the natural history of endometriosis. Hum Reprod 1990;5:965-70.

10 Telimaa S, Puolakka J, Ronnberg L, Kauppilla A. A placebo controlled comparison of danazol and high dose medroxyprogesterone acetate in the treatment of endometriosis. Gynecol Endocrinol

11 Evers $\mathrm{J}$. The second look laparoscopy for the evaluation of the results of medical treatment of endometriosis should not be performed during ovarian suppression. Fertil Steril 1987;47:502-4.

12 Thomas EJ. Endometriosis and infertility. In: Thomas EJ, Rock J, eds. Modern approaches to endometriosis. Dordrecht: Kluwer Academic, 1991:113-28.

13 Brosens IA, Verlayen A, Cornillie F. The morphologic effect of short term medical therapy of endometriosis. Am $\mathcal{F}$ Obstet Gynecol 1987;157:1215-21.

14 Sutton CJG. Laser laparoscopy in the treatment of endometriosis. In: Thomas EJ, Rock J, eds. Modern approaches to endometriosis. Dordrecht: Kluwer Academic, 1991:199-220.

\title{
Maintaining the treatment of mentally ill people in the community
}

\author{
Some compulsion is necessary, but for supervision, not treatment
}

Neglected social issues often attract the serious attention of the public and the government only as a result of a tragic and dramatic incident. The case of the mentally ill young man who climbed into an enclosure at London Zoo on 31 December and was mauled by a lion is the most recent example. ${ }^{1}$ The Secretary of State, Virginia Bottomley, at once committed herself to finding an urgent solution to the problem of maintaining the treatment of discharged patients suffering from chronic mental illness, who can all too easily be missed by current community psychiatric services.

This matter has preoccupied mental health workers for many years. The Royal Commission on Mental Illness and Mental Deficiency introduced the concept of guardianship, ${ }^{2}$ and the Mental Health Act 1959 gave the guardian wide powers of control. In effect, these were the same as the general powers of a parent over a child of less than 14 years. Such guardianship was seen as a way of protecting vulnerable people from exploitation, ill treatment, or neglect. The use of guardianship was never widely taken up, however, and in 1978 a total of 138 people were subject to it, of whom only 37 were mentally ill. The powers of control were considered too extensive and paternalistic.

Alternative approaches were subsequently proposed. In 1977 the British Association of Social Workers suggested community care orders. ${ }^{3} \mathrm{~A}$ white paper considered a changed form of guardianship, and ultimately the Mental Health Act 1983 incorporated a revised guardianship order with severely limited powers of control. Experience during the past nine years indicates that in its new form guardianship has not gained popularity, and many social workers consider both that it is unenforceable and that it may be an unethical constraint on individual freedom. ${ }^{4}$

Until 1985 many psychiatrists ensured the supervision in the community of patients who were known to default from treatment by granting them leave of absence. Detained under a section of the Mental Health Act in the first place, these patients had responded to treatment in hospital, and their leave was subject to a requirement that treatment should be continued outside hospital. Just before the section expired the patient would be readmitted, the detention order would be renewed, and the patient would again be given leave. This practice ended when it was declared unlawful by judicial review in 1985 ( $\mathrm{R} v$ Hallstrom ex parte $\mathrm{W}$ ), ${ }^{5}$ although under Scots law it continues with monitoring by the Mental Welfare Commission for Scotland.

There have since been a series of proposals to re-establish some form of compulsory treatment in the community from the Mental Health Act Commission (in $1986^{\circ}$ and again in $1988^{7}$ ), the Royal College of Psychiatrists (1987), ${ }^{8}$ and the British Medical Association (1989). ${ }^{9}$ None of these proposals found sufficient support to press the case forward, and at its conference in York in 1991 the Mental Health Act Commission voted against any specific recommendation. ${ }^{4}$ In other jurisdictions community treatment orders have been introduced with varying degrees of success. ${ }^{1011}$

Except for MIND most of the voluntary groups, such as the National Schizophrenia Fellowship and SANE, have expressed more positive enthusiasm for some measure of control, concerned that community care is too often an unfulfilled ideal that can become an impossible burden on relatives. The reluctance of all these campaigning bodies to reach a conclusion, however, has reflected a lack of consensus among their members, particularly for the proposal to enforce treatment in the community when the patient refuses consent. The suggestion for a community treatment order was rejected by some, on the grounds that it would infringe civil liberties, there was insufficient research to justify this extra measure, ${ }^{12}{ }^{13}$ the existing legislation provided a sufficient framework to give the necessary powers to deal with the problem, and changing the law might divert attention from the real need to provide resources to support an acceptable programme of community care. ${ }^{14}$

A working group of the Royal College of Psychiatrists has been taking a fresh look at the problem, and its report was endorsed by the college this week. It agrees that compulsory treatment in the community is unacceptable, but accepts that the "revolving door" patient who regularly defaults from treatment presents a genuine problem of management. The report recommends a new order, applicable only to patients with a history of non-compliance, which would provide for compulsory supervision of the patient in the community. Should the patient cease to accept treatment voluntarily and 
reject supervision, resulting in deterioration of his mental state, he or she could be recalled to hospital. Such intervention would prevent further deterioration, allow treatment to be re-established, and promote the patient's return to the community.

Such a measure means accepting that compulsory powers are necessary to ensure that this circumscribed group of detained patients are encouraged to maintain their continued care in the community, rather than to be frequently detained in hospital or to become a casualty in the community..$^{13}$ Nevertheless, its introduction must be accompanied by improved organisation of clinical services in the community, including better deployment of community psychiatric nurses to care for patients with severe long term psychiatric illness and the provision of essential resources. ${ }^{16}$

Professor of Forensic Psychiatry,

ROBERT BLUGLASS

University of Birmingham,

Reaside Clinic,

Birmingham B34 9BE
1 Wallace M. Tortured world of the man in the lions' den. Daily Mail 1993;Jan 2.

2 Royal Commission on the law relating to mental illness and mental deficiency. Report. Cmnd 169 London: HMSO, 1957. (Chairman: Lord Percy of Newcastle.)

3 British Association of Social Workers. Mental health crisis services - a new philosophy. Birmingham: BASW, 1977

4 The Mental Health Act Commission. Fourth biennial repon 1989-1991. London: HMSO, 1991.

5 Brahams D. Treatment of unco-operative psychiatric patients in the community. Mental Health Act in need of reform. Lancet 1986-i:863-4.

6 Mental Health Act Commission. Compulsory treatment in the community: a discussion paper. London: Mental Health Act Commission, 1986.

7 Mental Health Act Commission. Compulsory treatment of the mentally disordered in the community: the field of choice. London: Mental Health Act Commission, 1988.

8 Royal College of Psychiatrists. Community treatment orders-a discussion document. London: Royal College of Psychiatrists, 1987.

9 British Medical Association. Annual report of Council 1988-9. London: BMA, 1989.

10 Dedman P. Compulsory treatment orders in Victoria, Australia. Psychiatric Bulletin 1990;14:462-4.

11 Sensky T, Hughes T, Hirsch S. Compulsory treatment in the communiry I. A controlled study of compulsory community treatment with extended leave under the Mental Health Act: Special characteristics of patients treated and impact of treatment. British foumal of Psychiatry characteristics of

12 Dunn J. Community treatment orders: do we need them? Yournal of Forensic Psychiatry 1991;2: 153-66.

13 MurphyE. Community treatment orders: do we need them? fournal of Forensic Psychiatry 1991;3:175-6. 14 Birley J. Community treatment orders: do we need them? Journal of Forensic Psychiatry 1991;3:176-8.

15 Sensky T, Hughes T, Hirsch S. Compulsory treatment in the community. II. A controlled study of patients whom psychiatrists would recommend for compulsory treatment in the community. Brf Psychiatry 1991;158:799-804.

16 Royal College of Psychiatrists. The mental healih of the nation. London: Royal College of Psychiatrists, 1992.

\section{Respite care}

\section{Should be made less difficult}

The importance of caring for carers is gradually being recognised. Anyone in any doubt of the need for providing such support will find a gruelling account of the problems faced by carers of elderly people in Margaret Forster's novel Have The Men Had Enough?'

There are not only humanitarian but also financial reasons for caring for carers. In Britain in 1986 an estimated 1.3 million carers kept dependants out of institutions, providing some $£ 7 \cdot 3$ billion worth of informal care. ${ }^{2}$ If only one in 10 of those people cared for at home had instead to be looked after in residential institutions the additional public cost would exceed $£ 1$ billion a year. Yet despite the value of their work, carers' needs are often overlooked, and they do not constitute a very active pressure group-perhaps because so much of their energy goes into caring. Could respite care help?

Respite care takes several forms: the challenge is to match these forms with needs. Admitting someone to hospital for respite care permits review of their problems-medical or otherwise-and drug regimens. Intensive courses of treatment, such as physiotherapy, can be arranged. Nevertheless, hospitals provide only a small proportion of respite careperhaps as little as $7 \%{ }^{3}$ This may be appropriate, not only because hospital beds are usually expensive but also because most people prefer to be looked after in the community. ${ }^{4}$

The new Community Care Act should prompt a fresh look at services for carers and those they look after. It states that "A key responsibility of statutory service providers should be to do all they can to assist and support carers." Authorities need to be well informed about who their local carers are and their particular needs and preferences. Do they want home based respite care or would they prefer a separate facility for respite care? What form or forms should this take? Particular attention needs to be given to the preferences of different racial, cultural, and religious groups. Do authorities know how many carers belonging to ethnic minorities they have in their district, how many require respite facilities, and how they fare compared with other carers? Checking such consumer needs should result in resources being used better. Obtaining this information locally is important but takes skill. ${ }^{\circ}$

The Community Care Act may have negative as well as positive consequences. These include possible reductions in care in the community owing to inadequate funding and the knock on effects on hospitals, which may face even greater difficulties in returning elderly people to the community than at present. Such pressure on places in both the acute and community sectors might in turn lead to a squeeze on the provision of respite care. Already evidence exists of underprovision of respite care: one recent study reported that a quarter of carers had not had a holiday for more than five years, ${ }^{7}$ and another found that $40 \%$ of carers could not take a break when they wanted. ${ }^{3}$

Any possibility of further reductions in respite care should be strenuously resisted. The humanitarian reasons for safeguarding this provision should be sufficient in themselves. Coupled with the financial implications if carers decided they could no longer shoulder this burden the case for supporting respite care becomes overwhelming.

Consultant Physician,

DAVID GRIFFITH

Department of Health Care for Older People,

Mayday University Hospital,

Thornton Heath,

Surrey CR7 7YE

1 Forster M. Have the men had enough? London: Penguin, 1990.

2 Family Policy Studies Centre. Caring costs: the social security implications. London: Family Policy Studies Centre, 1986

3 Whatmore K, Mira-Smith C. Eldercare in the 1990's. Vol 3. Survey tables. London: National Carers Survey Research Team, 1991.

4 Social Services Inspectorate, Department of Health. Carer suppon in the community. London HMSO, 1991.

5 Secretaries of State for Health, Social Security, Wales, and Scotland. Caring for people: community care in the next decade and beyond - policy guidance. London: HMSO, 1989.

6 Robinson J, Yee L. Focus on carers. A practical guide to planning and delivering community care services. London: King's Fund Centre, 1991.

7 Jones DA, Peters TJ. Caring for elderly dependants: effects on the carers' quality of life. Age Ageing $1992 ; 21: 421-8$

\section{Correction}

\section{The patient's charter and the triage nurse}

An editorial error resulted in the wrong reference being given at the end of the first sentence of the second paragraph of this editorial by Tom Keighley and Jan Maycock (28 November 1992, p 1310). The correct reference should have been reference 3 . 